\title{
Самовдосконалення особистості і її самооцінка
}

Анотація. У статті розкрита роль самооцінки в процесі самовдосконалення особистості. Доведено, щео узагальнені результати пізнання себе і емоційно-ціннісного ставлення до себе втілюються у відповідну самооцінку, яка включається у регулящію поведінки особистості як один із визначальних аспектів. В результаті експериментального дослідження виокремлені рівні формування самооцінки підлітків і стариокласників, надана їх кількісна та якісна характеристика, яка доводить необхідність аналізу самоочінки у нерозривній єдності прочесів самопізнання, емоиійно-иіннісного ставлення особистості до себе і саморегуляиії.

Ключові слова: самосвідомість, самооцінка, самовдосконалення, самопізнання, саморегуляція, поведінка, пізнання.

Постановка проблеми і виклад матеріалу дослідження. Аналіз літературних джерел з досліджуваної проблеми приводить до висновку про багатоаспектність данного феномену і багатозначність його визначень. У багатьох роботах самовдосконалення розглядається як продукт самосвідомості або як компонент уявлень про себе. Більшість дослідників трактують дане явище як складну, багаторівневу систему когнітивних (пізнавальних), афективних (емоційних) і поведінкових складових.

Сучасні психологічні концепції різноманітні у своєму розумінні сутності феномену «Я», самосвідомості і самовдосконалення. Так, деякі $з$ авторів (І.С. Кон, В. В. Столін) розглядають як синоніми такі поняття як «Я», «Я-концепція», образ «Я», ідентичність, вбачаючи загальні риси у їх формуванні і проявах. Інші, навпаки, намагаючись подати структуру свідомості ієрархічно, наполягають на розмежуванні цих понять.

Зарубіжні автори широко використовують поняття «Я-концепція».

К. Роджерс розглядає «Я-концепцію» як організований і послідовний концептуальний гештальт, складений із сприйняття якостей «Я» (або «мене»), взаємовідносин «Я» 3 іншими людьми і $з$ різноманітними аспектами життя, а також цінностей, пов'язаних 3 даними сприйняттями. Він вважає, що даний гештальт доступний для свідомості, але не обов'язково усвідомлюваний, і зазначає, що як тільки гештальт усвідомлюється, відразу ж включається механізм оцінювання суб'єктом своїх якостей.

Р. Бернс уявляє «Я-концепцію» як сукупність усіх уявлень індивіда про себе, пов'язану з їх оцінкою. «Я-образ» розглядається як описова складова «Я-концепції», оцінна грань представлена в іiї структурі самооцінкою.

У психологічних роботах проблемам самооцінки приділяється значна увага (Б.Г. Ананьєв [1], Л.І. Божович [3], I. С. Кон [5], В.В. Столін [8], I. І. Чєснокова [9], К.В. Шорохова [10]). В зарубіжній психології дане питання вивчали: Р. Бернс [2], У. Джемс [4], К. Роджерс [6] та інші.

Більшість авторів одностайна у розумінні основних питань, пов'язаних з сприйманням і оцінкою особистістю самої себе, у визнанні багатоплановості структури самосвідомості, іii процесуальності, постійного розвитку. Процес усвідомлення себе відбувається у єдності когнітивної оцінки своїх можливостей, досягнень і емоційних реакцій, переживань $з$ приводу цієї оцінки, тобто, самоставлення. Самоставлення органічно пов'язане з самопізнанням, являє собою його емоційно-особистісну складову. Оскільки свідомість є знання про оточуючий світ і ставлення до нього (С. Л. Рубінштейн), самопізнання - єдність пізнання себе і ставлення до себе. 
Самопізнання і самоставлення починають формуватися на ранніх етапах життя, в сім'ї, яка є первинним базовим соціальним середовищем розвитку дитини. Очевидно, що дитина, яка позбавлена батьківської любові, має менше шансів на високу самоповагу і стійкий позитивний образ «Я». Жорсткі батьківські вимоги, заборони і покарання, з одного боку, сковують активність і ініціативність особистості, свободу iii самовираження, з іншого боку, сприймаючись як необгрунтовані і несправедливі, викликають у дітей протест і агресію. Послаблення батьківської уваги сприяє виникненню у дитини відчуття «покинутості», відсутності підтримки. Те, який стиль виховання домінує у сім'ї, накладає дієвий відбиток на процесс самовдосконалення особистості.

Мета дослідження полягала у з'ясуванні взаємозв'язку між самовдосконаленням та самооцінкою школярів. Для реалізації поставлених завдань ми застосували анкету для визначення самооцінки, у якій просили підлітків і старшокласників (досліджувані - учні 8, 11 класів СЗШ № 184 м. Києва) оцінити ступінь наявності в себе поданих характеристик, які стосуються процесу самовдосконалення особистості. Наводимо їх для прикладу.

Цінності, пов'язані з оцінкою зовнішності: мати красиву зовнішність; виглядати дорослішим; бути успішним. Соціальнокомунікативні цінності: мати теплі взаємини з батьками та родиною; мати хороші стосунки з друзями та оточуючими; користуватись авторитетом у школі. Матеріальні цінності: заробляти на життя; купувати дорогі речі; забезпечити собі матеріальний комфорт. Цінності самореалізації: виховувати у собі творче ставлення до праці, бути готовим до свідомого вибору майбутньої професії; розвивати власні пізнавальні інтереси і творчу активність при опануванні знань; уміти самостійно здобувати знання, постійно знайомитися 3 новими досягненнями науки і техніки. Морально-етичні i естетичні цінності: самореалізуватись як духовна особистість; оволодівати національною культурою і духовною спадщиною свого народу; уміти діяти у відповідності з власними переконаннями та брати участь у житті країни.

Читаючи даний список, учні повинні були оцінити міру наявності у себе цих якостей і записати у графу анкети за шестибальною шкалою. Отримані результати зіставлялися 3 рейтингом вчителів. Показником адекватності самооцінки була міра iii відповідності результатам об'єктивної оцінки.

Розглянемо, як розподіляються одержані експериментальні дані відповідно до рівнів самооцінки. Найбільший відсоток в усіх класах становлять відповіді, що відносяться до 1 (високого) рівня (8 кл. $-54 \%$; 11 кл. - $60 \%$ ).

Високий рівень - повне розуміння сутності основних ознак поняття «самовдосконалення особистості», позитивне власне ставлення до тих обов' язків, які з нього випливають, звичка діяти згідно 3 цими цінностями у житті. Особистість розвивається досить гармонійно. Самооцінка дітей $\epsilon$ реалістичною: вони оцінюють позитивно означені цінності. Школярам, що перебувають на цьому рівні, властивий не лише високий ступінь усвідомлення, розуміння ціннісних норм, але й висока здатність до саморегуляції відповідно з внутрішньо прийнятими моральними настановленнями. На даному рівні в учнів поступово виникає узагальнений образ «Я»: через самосприйняття, самоспостереження і самоаналіз. Школярі з високим рівнем самооцінки знають свою мету і цінності, дивляться оптимістично у майбутнє, беруть на себе відповідальність за результати власної діяльності, не виокремлюють себе поміж інших, не бояться своїх почуттів і здатні відстоювати їх тощо. Представники даного рівня приймають активну участь у житті суспільства, школи, мають досвід соціальних взаємин як у шкільному колективі, так і в сім’ї. Що стосується відповідей 2 (середнього) рівня, то у учнів 8 класів відсоток дещо вищий і становить $35 \%$, у 11 класах $-28 \%$.

Середній рівень - неглибоке, часткове розуміння сутності відповідних ознак, 
нестійке або індиферентне ставлення до цього поняття. Слабка самооцінка призводить до того, що учень переоцінює або недооцінює себе, а рівень його прагнень не відповідає рівню фактичних досягнень. В той же час спостерігається ріст пізнавальних можливостей школяра, підвищення уваги до свого «Я» і здатності до самоспостереження. У дитини з'являється бажання до самозмін, до пошуку зразків для наслідування. Порівняння себе 3 іншими - важливий механізм розвитку самооцінки особистості. На даному етапі диференціюється зміст оцінки, ускладнюється iï структура, зростає критичність по відношенню до себе. Становлення самооцінки характеризується ланкою протиріч: у одних сферах зростає її стабільність, в інших навпаки; в той же час зростання самокритичності межує з невпевненістю i конфліктністю з однолітками і дорослими. Такі протиріччя призводять до нестійкої самооцінки.

В експерименті визначилась приблизно однакова частка досліджуваних 33 (низьким) рівнем самооцінки (8 кл. - $11 \%$, 11 кл. - $12 \%$ ).

Низький рівень - нерозуміння учнем суті найважливіших характеристик поняття «самовдосконалення особистості», або ж негативне ставлення до нього. Характеризується майже повною відсутністю у розумінні дітей цінностей самовдосконалення. Критерії оцінок неадекватні. Індивідуальні відповіді не аргументовані, оцінні ставлення до засвоюваних знань (понять, оцінок, норм) ще не стали регуляторами їх свідомості і поведінки. Учні, що відносяться до даної категорії, не здатні до саморегуляції. У них спостерігається низький взаємозв'язок між емоційними, раціональними проявами поведінки і рівнем вияву переконань у вчинках. Самооцінка характеризується ситуативністю, залежністю від зовнішніх факторів. Такі школярі легко піддаються негативним впливам соціуму, відзначаються низькою самокритичністю, невмінням прогнозувати результати своїх негативних вчинків, їм важко протистояти власним егоїстичним намірам тощо.
Ми порівняли отримані результати 3 рейтингом учителів. Це дало підстави стверджувати, що виокремлені рівні самооцінок у наших досліджуваних не слід розглядати як протилежності. Якщо учні не приписують собі високих балів, це не означає, що вони сприймають себе як некомпетентних, нічого не вартих. Те ж саме стосується і середніх балів. Їх низькі і середні бали - не абсолютні. Вони відносні стосовно учнів з високим рівнем самооцінки. Можливо, низька самооцінка $\epsilon$ реалістичною: досліджувані об'єктивно оцінюють свої можливості. Крім того, учні з низькою самооцінкою недостатньо добре себе знають, їх уявлення про себе невизначені, вони невпевнені, залежні від обставин, оцінок інших людей, вони постійно потребують допомоги. 3 точки зору деяких авторів, в учнів з низькою самооцінкою спостерігається велика розбіжність між «Я реальним» і «Я ідеальним», яка об'єктивно сприймається як неможливість для подолання цього явища, в той час як досліджуваних 3 високою самооцінкою характеризує незначний розрив між цими рівнями «Я». Аналіз особливостей низької самооцінки свідчить про те, що учням важко виконувати свої обов'язки. Там, де потрібно приймати самостійне рішення, вони діють не кращим чином, не намагаються досягти успіху, підвищити свою самооцінку.

У психологічних дослідженнях доведено, що успішному розвитку самооцінки в підлітковому і юнацькому віці сприяють настановлення батьків на прийняття дитини і демократичні взаємини 3 нею. Діти 3 таких сімей відзначаються високим інтелектуальним розвитком, емоційною впевненістю, розвиненим самоконтролем. В той час дітям $з$ авторитарних сімей властива емоційна вразливість, агресивність, відчуженість.

Важливу роль у формуванні самооцінки відіграє школа. Досить часто учень оцінюється завдяки успішності розв'язання навчальних задач. Якщо дитина відстає у навчанні, то до переживання власних невдач додаються негативні оцінки вчителів, 
батьків. Отже, успіхи та невдачі учня формують його самооцінку. Якщо оцінка адекватна, то дитина усвідомлює власну цінність та свої можливості і здібності, вона поважає себе і не принижує інших. Школярі з завищеною самооцінкою особливо гостро реагують на невдачі. Дані реакції характеризуються або запереченням самого випадку невдачі, або перекладанням відповідальності на інших і виявляються в підвищеній вразливості, підозрілості, агресивності, негативізмі. В психології ці емоційні реакції отримали назву «афекту неадекватності». Такий стан найбільш характерний для дітей, у яких в минулому досвіді утворилася стійка завищена самооцінка і відповідно завищений рівень домагань. Школяр відмовляється навіть думати про свою неспроможність, і тому відкидає свою невдачу, спотворюючи факти, які свідчать про його поразку. Такі афективні зриви мають місце у тих випадках, коли у дітей не існує погодження між свідомою високою самооцінкою, високими домаганнями, що виходять за рамки дійсних можливостей, і неусвідомлюваною впевненістю у собі.

Аналіз співвідношення самооцінки i рівня домагань за параметром адекватності показав, що при неадекватності хоча б одного параметру виявляється цілий мотиваційно-афективний комплекс: незадоволення нинішньою ситуацією, відсутність чітких ідеалів, брак впевненості у собі; знижується емоційна стабільність, спостерігається орієнтованість на безконфліктну взаємодію заради налагодження корисних зв'язків, що продиктовано, з одного боку, дружелюбністю і настановленням на співробітництво, з іншого - прагненням до лідерства в поєднанні з невпевненістю у власних силах.

У підлітковому віці роль самооцінки в житті дитини зростає, відбувається переорієнтація з зовнішніх оцінок на самооцінку. Змінюється і зміст їі: наявність змін у зовнішньому вигляді, взаємини $з$ друзями, батьками, вчителями, особистісні якості i можливості аналізуються, порівнюються 3 такими ж якостями ровесників і значущих дорослих, відбувається усвідомлення різниці між «Я реальним» і ідеальним. «Я-концепція» підлітка спочатку нестійка, відсутній єдиний принцип самооцінювання, мають місце різкі зміни в самооцінках. Уявлення дітей про себе непослідовні. Нестійка «Я-концепція» призводить до того, що кожна конкретна самооцінка може коливатися від самовпевненості до повного несприйняття «власного Я». На кінець підліткового віку самооцінка стає більш стійкою і узагальненою, незалежно від ситуації оцінювання.

У юнацькому віці, порівняно з підлітковим, самооцінка стає більш позитивною, стійкою і незалежною. У даний період важливу роль у процесі самооцінювання відіграють зовнішні умови: соціальне визнання, фізична привабливість, досягнення, успіхи тощо. Пошук «власного Я», своїх внутрішніх цінностей сприяє співставленню себе з іншими. І лише досягнення цілісної і стійкої «Я-концепції», розуміння і прийняття «Я» в усіх його аспектах дозволяє старшокласникам спиратися на свою ідентичність і бути менш залежними від зовнішніх факторів і оцінок.

Висновки. Самооцінка $\epsilon$ центральним утворенням у процесі самовдосконалення особистості. Основна їі функція у психічній діяльності полягає в тому, що вона є необхідною умовою саморегуляції поведінки. Вища форма саморегуляції - творче ставлення до власної особистості, намагання змінити, покращити себе. Формування самооцінки пов'язане 3 особливостями взаємин учня 3 навколишнім світом. 3 зростанням інтелектуального розвитку дитина із оцінок оточуючих постійно виокремлює критерії і способи оцінювання інших і переносить їх на себе, що складає основний механізм розвитку самооцінки у підлітковоому віці. Становлення останньої в юнацькому віці пов'язане 3 появою таких якостей, як компетентність, почуття власної гідності, впевненість у собі тощо. 


\section{Список використаних джерел:}

1. Ананьев Б. Г. Человек как предмет познания / Б. Г. Ананьев. - Л. : ЛГУ, 1968. - 338 с.

2. Бернс Р. Развитие Я-концепции и воспитание / Р. Бернс. - М. : Прогресс, 1986.

3. Божович Л.И. Личность и ее формирование в детском воздасте / Л.И. Божович. - М. : Просвещение, 1968. — 464 с.

4. Джемс У. Личность / У. Джемс // Психология самосознания : Хрестоматия. - Самара : БАХРАХ-M, 2000. - С. 7-44.

5. Кон И.С. От самооценки - к «образу Я» / И.С. Кон // Психология самосознания : Хрестоматия. - Самара : Издательский Дом «Бахрах-М», 2003. - С. 57-74.

6. Роджерс К. Вчитися бути вільним / К. Роджерс // Гуманістична психологія : Антологія в 3-х т. / За ред. Р. Трача і Г. Балла. — Т. 1. - К., 2001. — 252 с.

7. Рубинштейн С. Л. Проблемы общей психологии / Отв. ред. Е. В. Шорохова. - М. : Педагогика, 1976. - $416 \mathrm{c.}$

8. Столин В.В. Самосознание личности / В. В. Столин. - М. : Изд-во МГУ, 1983. — 286 с.

9. Чеснокова И. И. Проблемы самосознания в психологии / И. И. Чеснокова. - М. : Наука, 1977.

10. Шорохова Е.В. Проблемы «Я» и самосознание / Е. В. Шорохова // Проблемы сознания : материалы симпозиума. - М., 1966. - С. 217-228.

Аннотация. В статье раскрыта роль самооценки в процессе самосовершенствования личности. Доказано, что обобщенные результаты познания себя и эмочиональноценностного отношения к себе воплощаются в соответствуюшую самооценку, которая включается в регулячию поведения личности как один из определяющих аспектов. В ходе експериментального исследования выделены урони формирования самооценки у подростков и старшеклассников, представлена их количественная и качественная характеристика, доказывающая необходимость анализа самооченки в неразрывном единстве процессов самопознания, эмоционально-ценностного отношения личности к себе и саморегуляиии.

Ключевые слова: самосознание, самооченка, самосовершенствование, самопознание, саморегуляиия, поведение, познание.

Abstracts. In the article the role of self-esteem in the process of self-improvement personality is observed. It is proved that the generalized results of self-knowledge and emotional-evaluative attitude to himself embodied in appropriate self-esteem, which is included in the regulation of a person's behavior as one of the defining aspects. During the new experimental study highlighted drop formation of self-esteem in adolescents and high school students, and presented their quantitative and qualitative characteristics which prove the necessity of self-assessment analysis in the inseparable unity of the processes of self-knowledge, emotional-value relationship of the individual to himself and self-regulation. Keywords: self-awareness, self-esteem, self-improvement, self-knowledge, self-regulation, behavior, cognition. 